\title{
Composition and specific gravity of milk of West African Dwarf sheep as affected by stage of lactation and parity \\ T.J. Williams ${ }^{1}$, I.J. James ${ }^{1}$, M.R. Abdulateef ${ }^{1}$, L.O. Onabegun ${ }^{1}$, S.O. Jinadu ${ }^{1}$, Y.O. Falade ${ }^{1}$, F.T. Solola ${ }^{1}$, O.O. Adewumi ${ }^{2}$ and O.E. Oke ${ }^{1}$ \\ ${ }^{1}$ Department of Animal Physiology, ${ }^{2}$ Department of Animal Production and Health, University of Agriculture, P.M.B. 2240, Abeokuta, Ogun State Nigeria Corresponding author: tolwilly@gmail.com
}

\begin{abstract}
Twelve matured lactating ewes weighing between 16 and $24 \mathrm{~kg}$ live weight were used to evaluate the effects of stage of lactation and parity on milk composition and specific gravity of milk of West African Dwarf (WAD) sheep in a semi-intensive system of management. Stage of lactation was divided into 4: early, mid, late and very late respectively with 3 weeks interval. The animals were of parities 1 and 2 and were allowed to graze on an established paddock in the University Farm for 5 hours and supplemented with concentrate $(17 \% \mathrm{CP}, 5 \% \mathrm{BW})$ daily. Animals were hand milked once daily at 8.00 am for 12 weeks. Stage of lactation significantly $(P<0.05)$ affected specific gravity of milk while parity did not have any significant effect. Daily milk mass and daily milk volume decreased linearly, from early to very late stage of lactation; 158.276 to $34.411 \mathrm{~g}$ and 156.054 to $34.410 \mathrm{~cm}^{3}$ respectively. Average composition of milk components were $3.78 \%, 4.49 \%, 0.76 \%, 4.99 \%, 9.02 \%$ and $14.00 \%$ for protein, lactose, ash, fat, solid non-fat and total solids respectively. Stage of lactation significantly $(P<0.001)$ affected milk protein, lactose, fat, solid non-fat and total solid except ash. However, parity did not significantly affect any of these milk constituents. The contents of total solids, solid non-fat, fat and protein were positively correlated with. On the other hand, phenotypic correlations between lactose, protein and fat were negative. It was concluded that stage of lactation exerts significant influence on specific gravity and composition of milk of WAD sheep while parity did not.
\end{abstract}

Keywords: stage of lactation, parity, specific gravity, ewe milk, composition

\section{Introduction}

Milk is regarded as a heterogeneous emulsion, secreted in the mammary gland of a normal healthy, female animal at parturition. Milk yield is dependent on the amount of secretory tissue and the rate of milk secretion (per unit of time). Milk production increases with increase in lactation stage (Ahamefule et al., 2000) until it reaches a peak about four-five lactation and then declines due to increase in age (Chamberlain, 1989). Milk is very rich in nutrients. It contains calcium, fat, phosphorus, protein, and lactose and good for ulcer patients due to its alkaline nature. Local sheep breeds in Nigeria (Yankasa, Ouda, Balami and WAD) have the potential to supply a significant portion of the milk deficit in the country because sheep numbers far exceed cattle in both rural and urban communities; 33 million sheep as against 16 million cattle (NPFS, 2008: Adewumi, 2005). Sheep shows less susceptibility to mastitis than other ruminants (Anyam and Adekeye, 1985). They are also more affordable to resourcepoor families and produce more milk in relation to body size than cattle (Nuru, 1985). Unlike cow or goat milk, sheep milk is used, due to its specific composition, almost exclusively for the production of cheese so that its quality is based not only on its nutrient content but also on its renneting ability (Kuchtík et. al., 2008). 
The high digestibility and high content of vitamin $\mathrm{B}_{1}$ have been implicated in the effects of sheep milk in relieving stress like constipation and insomnia. Sheep milk is good for children and adult people allergic to cow milk. According to Devendra and Burns (1983), Ehoche and Buvanendran (1983), Said and Al-Jaryan (1992); Singh et al. (1993), Khatkar and Sethi (1995) and Adewumi et al., (2003), factors that affect milk yield in dairy animals include genetic and environmental factors. Such factors are parity (lactation number), stage of lactation, age of animals, live-weight, age at first parturition, udder and teat dimensions, litter size, season/year of parturition, lactation length and of course nutrition. Specific gravity is the ratio of the density of milk compared to the density of water at a certain temperature, when both are weighed in air. Temperature drops lead to increase in specific gravity of milk. Over the years, local milk production has consistently fallen short of demand, especially in urban centre, leading to importation of milk and milk products. Continuous dependence on imported milk has discouraged local milk production and led to increase in cost of milk and its products. Although there is a strong affinity for milk products in the country, the high cost of milk has put these products beyond the reach of the average Nigerian, hence it is necessary to look for alternative source of milk for local consumption. In spite of the potentials of our local sheep, the animals have largely been neglected by researchers in the quest for increased good quality milk production It is therefore the objective of this study to evaluate the effect of stage of lactation and parity on specific gravity and composition of milk of WAD sheep.

\section{Materials and methods}

The experiment was conducted at the Sheep Unit of the College of Animal Science and Livestock Production Farm, University of Agriculture, Abeokuta Nigeria (UNAAB), located at latitude $7^{\circ} 13^{\prime} \quad 49.46^{\prime} \mathrm{N}$ and longitude $3^{\circ} .2611 .98^{\prime} \mathrm{E}$ (Google Earth, 2006). The climate is humid with mean annual precipitation and relative humidity of $1,112.7 \mathrm{~mm}$ and $81.5 \%$ respectively. Seasonal distribution of rainfall is approximately $110.9 \mathrm{~mm}(9.97 \%)$ in the late dry season (Jan - March), $462.1 \mathrm{~mm}$ $(41.53 \%)$ in the early wet season (April June), $376.6 \mathrm{~mm}(33.85 \%)$ in the late wet season (July-Sept) and $163.1 \mathrm{~mm}(14.66 \%)$ in the early dry season (Oct. - Dec.) (ORBDA, 2004).

Experimental animals and their management

The experiment involved 12 lactating ewes (4 parity 1 and 8 parity 2 respectively). The animals were selected from the herd of the Sheep Unit of the farm. They were semiintensively raised throughout the period of the study. All the animals were housed in open-sided wooden and roofed pens with slatted floor. The ewes were allowed to graze in the established paddock feeding on grasses such as Panicum maximum, Pennisetum purpureum and legumes (Tridax procumbens,Stylosanthes hamata). The animals were also given concentrates $(17 \%$ CP) at $5 \%$ body weight as a supplementary feed in addition to their basal diet. They were provided with drinking water ad-libitum.

Experimental procedure The twelve lactating ewes in their first and second parities were hand milked once daily for the period of twelve weeks. Lambs were separated from their dams at $5 \mathrm{pm}$ in the evening and milking was done at 8 am 
the following day. The 12 weeks lactation period was divided into early (first 3 weeks), mid (next 3 weeks), late (next 3 weeks) and very late (last 3 weeks).

Determination of specific gravity

The specific gravity was determined using the mass and volume of the milk yield recorded. Since the specific gravity of a substance is expressed as ratio of density of the substance to the density of water in $\left(\mathrm{g} / \mathrm{cm}^{3}\right)$. The milk collected was weighed using electronic sensitive scale to determine the mass of the milk yield and measuring cylinder to determine the volume of the milk for each of the lactating ewes. The 15-hour milk yield was divided by 15 and multiplied by 24 to obtain daily milk yield. Specific gravity of milk was computed by dividing daily milk mass (g) by daily milk volume $\left(\mathrm{cm}^{3}\right)$ and then dividing the result by density of water (1 $\left.\mathrm{g} / \mathrm{cm}^{3}\right)$.

$$
\text { Density of milk }=\frac{\text { mass of milk yield }(\mathrm{g})}{\text { Volume of milk yield }\left(\mathrm{cm}^{3}\right)}
$$

Specific gravity of milk $=$ Density of milk Density of water

Determination of milk composition

Milk collected from the ewes was analyzed in the laboratory of the Department of Animal Physiology, UNAAB. Total solids (\%) was determined gravimetrically, by oven drying at $102{ }^{\circ} \mathrm{C}$ to constant weight. The samples were ashed by charring in a Muffle furnance at $500 \Sigma \mathrm{C}$ for about three hours. The protein (\%) in the milk was determined according to Kjeldahl procedure (AOAC, 1980). Milk fat (\%) was determined according to Gerber's procedure (1960). Solid non-fat content (\%) was computed by subtracting milk fat content from total solids. Lactose (\%) was computed as the last solid after subtracting
Table 1: Gross composition of concentrate feed for WAD sheep.

\begin{tabular}{ll}
\hline Ingredient & $\mathbf{\%}$ \\
\hline Maize & 5 \\
Dry brewers grain (BDG) & 35 \\
Palm kernel cake & 18 \\
Bone offal & 40 \\
Bone Meal & 1 \\
Common Salt & 1 \\
& \\
Calculated Analysis \% & \\
Crude protein & \\
Crude fibre & 16.84 \\
Either extract & 12.66 \\
Calcium & 4.78 \\
Available phosphorus & 0.52 \\
Metabolizable energy & 0.34 \\
(k/cal/kg) & \\
\hline
\end{tabular}

other solids (fat, protein, ash) from total solids. Table 1 show the composition of the concentrate fed to the animals. Data collected were analyzed for variance and correlations as contained in Systat (1993). The model used is as follows:

$\mathbf{Y}_{\mathrm{ijk}}=\mu+A_{i}+B_{j}+A_{B_{i j}}+E_{i j k}$

Where

$\mathrm{Y}_{\mathrm{ijk}}=$ Milk yield, $\left(\mathrm{cm}^{3}, \mathrm{~g}\right)$

$\mu=$ The overall mean

$A_{i}=$ The fixed effect of the $i^{\text {th }}$ stage of lactation $(i=1-4)$

$B_{j}=$ The fixed effect of the $j^{\text {th }}$ parity $(j=1-2)$

$\mathrm{AB}_{\mathrm{ij}}=$ The interaction between stage of lactation and parity

$E_{i \mathrm{ij}}=$ Random error

\section{Results and discussion}

The results of the analyses on the effect of stage of lactation and parity on specific gravity of milk, daily milk mass and daily milk volume showed that stage of lactation was highly significant $(\mathrm{P}<0.001)$ on daily milk volume and daily milk mass while parity was not. The interaction between parity and stage of lactation was also not 
Table 2: Least square means on the effects of stage of lactation and parity on specific gravity of milk, total daily milk mass, total daily milk volume and density of West African Dwarf (WAD) sheep

\begin{tabular}{cllllll}
\hline $\begin{array}{l}\text { Source of } \\
\text { variance }\end{array}$ & Sub class & $\begin{array}{l}\text { No. of } \\
\text { observation }\end{array}$ & $\begin{array}{l}\text { Daily milk } \\
\text { mass }(\mathrm{g})\end{array}$ & $\begin{array}{l}\text { Daily milk } \\
\text { volume }\left(\mathrm{cm}^{3}\right)\end{array}$ & $\begin{array}{l}\text { Specific gravity } \\
\text { of milk }\end{array}$ & $\begin{array}{l}\text { Density } \\
\left(\mathrm{g} / \mathrm{cm}^{3}\right)\end{array}$ \\
\hline Stage & Early & 44 & $158.276 \pm 8.477^{\mathrm{a}}$ & $156.054 \pm 8.275^{\mathrm{a}}$ & $1.011 \pm 0.009^{\mathrm{b}}$ & 1.014 \\
\multicolumn{1}{c}{ of } & Mid & 96 & $129.777 \pm 5.422^{\mathrm{b}}$ & $127.738 \pm 5.293^{\mathrm{b}}$ & $1.016 \pm 0.006^{\mathrm{a}}$ & 1.015 \\
lactation & Late & 96 & $82.623 \pm 5.422^{\mathrm{c}}$ & $81.288 \pm 5.293^{\mathrm{c}}$ & $1.021 \pm 0.006^{\mathrm{a}}$ & 1.016 \\
& Very late & 52 & $34.411 \pm 7.139^{\mathrm{d}}$ & $34.410 \pm 6.969^{\mathrm{d}}$ & $0.988 \pm 0.007^{\mathrm{b}}$ & 1.000 \\
& & & & & & \\
Parity & First & 96 & $101.256 \pm 5.541$ & $100.038 \pm 5.409$ & $1.009 \pm 0.006$ & 1.012 \\
& Second & 162 & $101.287 \pm 3.834$ & $99.706 \pm 3.743$ & $1.009 \pm 0.000$ & 1.015 \\
\hline
\end{tabular}

$\overline{A, b, c, d}$ Means with supers cript on the same column are significantly different $(\mathrm{P}<0.05)$

significant. The increase in specific gravity of milk as stage of lactation progressed could be due to protein content which increases density as lactation advances. The result agrees with the findings of Ahamefule et al. (2000) who stated that protein increases with advance lactation. The result is however, slightly different from data published by Voutsinas et al. (1988) and Sahan et al. (2005) who observed that specific gravity of sheep milk decreased during the first six or seven weeks of lactation and thereafter remain relatively stable until the end of lactation. The reason may also be due to nutritional factor and management. The animals were fed a concentrate of about $17 \%$ crude protein apart from their basal diet. They were also managed semi intensively.

The least square means on the effect of stage of lactation and parity on specific gravity of milk, daily milk mass and daily milk volume are shown in Table 2 . The early stage had the highest milk mass and volume; $158.276 \mathrm{~g}$ and $156.054 \mathrm{~cm}^{3}$ respectively. The yield gradually declines as lactation advances to $34.411 \mathrm{~g}$ and $34.410 \mathrm{~cm}^{3}$ respectively. This trend of milk yield could have resulted due to proliferation of myoepithelial cells of the mammary gland especially at the early stage of lactation. This result is similar to the findings of Knight and Wilde (1993), who reported that mammary cells multiplied during early lactation and declines as lactation progresses. The result also agrees with the reports of Bemji (2003), James (2000), Oddy et al. (1984) and Williams (2008). It was also reported by Chamberlain (1989) that milk production gradually declines after reaching its peak. The decline in milk yield as lactation stage increases is attributed both to loss of secretory tissues and fall in the rate of secretion per cell.

Average composition of milk of WAD sheep was found to be; protein $3.78 \%$, lactose $4.49 \%$, total solid $14.00 \%$, ash $0.76 \%$, and fat $4.97 \%$ (Table 3 ). The protein and ash contents obtained in this study were lower than $5.7 \%$ and $0.9 \%$ reported by Adewumi et al., (2005) while lactose, fat and total solids were comparable. The effect of stage of lactation on protein, solid non-fat and total solid was highly significant $(\mathrm{P}<0.001)$. Protein, solid nonfat and total solids increased as lactation progressed thus corroborating the reports of 
Table 3: Least square mean showing the effect of stage of lactation and parity on milk composition of West Africa Dwarf sheep (\%)

\begin{tabular}{|c|c|c|c|c|c|c|c|c|}
\hline $\begin{array}{l}\text { Source of } \\
\text { Variation }\end{array}$ & $\begin{array}{l}\begin{array}{l}\text { Sub } \\
\text { class }\end{array} \\
\end{array}$ & $\begin{array}{l}\text { No. of } \\
\text { observ } \\
\text { ation }\end{array}$ & Protein & Lactose & Ash & Fat & Solid non-fat & Total solid \\
\hline Stage & & & & & & & & \\
\hline of & $\begin{array}{l}\text { Early } \\
\text { Mid }\end{array}$ & $\begin{array}{l}22 \\
49\end{array}$ & $\begin{array}{l}3.349+0.104^{\mathrm{c}} \\
3.764+0.068^{\mathrm{ab}}\end{array}$ & $\begin{array}{l}3.426+0.427^{\mathrm{c}} \\
4.568+0.271^{\mathrm{b}}\end{array}$ & $\begin{array}{l}0.752+0.028 \\
0.759+0.018\end{array}$ & $\begin{array}{l}4.216+0.176^{\mathrm{c}} \\
4.844+0.112^{\mathrm{b}}\end{array}$ & $\begin{array}{l}7.528+0.437 \\
9.091+0.278\end{array}$ & $\begin{array}{l}11.743+0.438^{\mathrm{c}} \\
13.935+0.279^{b}\end{array}$ \\
\hline & Late & 47 & $3.959+0.67^{\mathrm{a}}$ & $4.311+0.274^{\mathrm{ab}}$ & $0.741+0.018$ & $5.296+0.113^{\mathrm{a}}$ & $9.010+0.281$ & $14.307+0.282^{2 \mathrm{~b}}$ \\
\hline lactation & $\begin{array}{l}\text { Very } \\
\text { late }\end{array}$ & 26 & $3.652 \pm 0.088^{\mathrm{bc}}$ & $5.744 \pm 0.359^{\mathrm{a}}$ & $0.794 \pm 0.024$ & $5.072 \pm 0.148^{\mathrm{ab}}$ & $10.190+0.368$ & $15.262 \pm 0.369^{\mathrm{a}}$ \\
\hline Parity & $\begin{array}{l}\text { First } \\
\text { Second }\end{array}$ & $\begin{array}{l}48 \\
96\end{array}$ & $\begin{array}{l}3.608 \pm 0.068 \\
3.754+0.047\end{array}$ & $\begin{array}{l}4.621 \pm 0.279 \\
4.404+0.193\end{array}$ & $\begin{array}{l}0.757 \pm 0.019 \\
0.766+0.013\end{array}$ & $\begin{array}{l}4.722 \pm 0.115 \\
4.991+0.080\end{array}$ & $\begin{array}{l}8.986+0.285 \\
8.923 .+0.197\end{array}$ & $\begin{array}{l}13.708 \pm 0.286 \\
13.915+0.198\end{array}$ \\
\hline
\end{tabular}

Means with superscript abc on the same column differ significantly $(\mathrm{P}<0.05)$

Fuertes et al. (1998), Adewumi et al., (2005) and Kuchtík et al. (2008), who reported gradual but steady increase in protein, solid non-fat and total solids with advancement in lactation. The result is however, contrary to $5.5 \%$ and $16.3 \%$ for protein and total solid obtained for sheep by Jenness, (1980). The effects of stage of lactation and parity on ash were not significant $(\mathrm{P}>0.05)$. This result agrees with the findings of Akinsoyinu (1981), Bath et al. (1978), Dangut (1991) and Jenness (1980). The effect of stage of lactation on milk fat was highly significant $(\mathrm{P}<0.001)$. This result is similar to the report of Jenness, (1980) who reported $5.3 \%$ fat for sheep. Fat \% increased as lactation progressed. This agrees with the report of Ploumi et al. (1998) and Adewumi et al. (2005) who observed that milk fat \% increases continuously during the milking process. First drawn milk may contain only $1-2 \%$ fat, whereas, at the end of milking, fat
$\%$ may be $5-10 \%$. This is because of the tendency of the fat globules to cluster and be trapped in the alveoli. Thus after incomplete milking, milk fat content will be lower than normal. Residual milk (milk remains in the udder after milking) may contain up to $20 \%$ fat.

The phenotypic correlations of all milk components are summarized in Table 4. Phenotypic correlations between total solids, solid non-fat, fat and protein were positive and high $(\mathrm{P}<0.001)$. Pavič et al. (2002) also reported that the contents of total solids, solid non-fat, fat and protein were highly and positively correlated with each other.

\section{Conclusion}

Stage of lactation had significant effect on specific gravity, density, daily milk mass and daily milk volume of West African Dwarf sheep. Stage of lactation also had significant effect on milk contents except

Table 4: Correlation showing effect of stage of lactation on milk composition of WAD sheep

\begin{tabular}{lllllll}
$\begin{array}{l}\text { Sources of } \\
\text { variation }\end{array}$ & $\begin{array}{l}\text { Stage of } \\
\text { lactation }\end{array}$ & Protein & Lactose & Ash & Fat & $\begin{array}{l}\text { Solid non- } \\
\text { fat }\end{array}$ \\
\hline Protein & 0.194 & & & & \\
Lactose & 0.267 & -0.049 & & & \\
Ash & 0.054 & -0.066 & 0.127 & & \\
Fat & $0.335^{* * *}$ & 0.310 & -0.148 & -0.016 & & \\
Solid non-fat & 0.312 & 0.203 & $0.966 * * *$ & 0.167 & -0.066 & \\
Total solids & $0.427 * * *$ & 0.314 & $0.856 * * *$ & 0.151 & 0.331 & 0.920 \\
\hline$* * *(\mathrm{P}<0.001)$ & & & & & &
\end{tabular}


ash. The contents of total solids, solid nonfat, fat and protein were positively correlated with each other. Parity did not have any significant effect on any of the parameters considered. Based on the results of the study, for purposes that required dense milk, it is advised that milk collection be done at late stage of lactation (about 6 weeks from the commencement of lactation).

\section{Acknowledgement}

The authors wish to thank the Director (Mr. J.J. Olobasola) of Teaching and Research Farm Directorate of the Universitry of Agriculture Abeokuta and the personnel of the Sheep and Goat Unit of the Farm.

\section{References}

Adewumi, O.O., Alokan, J. A. and Ologun, A. G. 2003. The relationship between some body measurement and milk yield in sheep milk. Journal of Agriculture, Forestry and Fishries. 4: 44-48.

Adewumi O.O. 2005. Sheep milk: the most important but neglected source of protein. Proceedings of the $10^{\text {th }}$ Annual Conference of Animal Science Association of Nigeria, University of Ado-Ekiti, Nigeria September 12 - 15, 2005, pp 237-239.

Adewumi O.O., Alokan, J. A. and Ologun, A. G. 2005. Milk yield, chemical constituents and stage of lactation in sheep. Proceedings of the $10^{\text {th }}$ Annual Conference of Animal Science Association of Nigeria, University of Ado-Ekiti, Nigeria September 12 - 15, 2005, pp $240-$ 242.

Ahamefule, F.O Ibeawwuchi, J.A. Ejiofor,C.A , 2000. A comparative study of the constituents of the milk of cattle, sheep and goats in a hot humid tropical environment. Journal of Sustainable Agriculture and the Environment. 2(2): 168-173.

Akinsoyinu A.O. 1981. The composition of milk of the Fresian cattle imported to Nigeria Sci. Fd. Agric. 32, 863-867.

Anyam A. A. and Adekeye J. O. 1985. Bacteria flora associated with mastitis in sheep and goat in Zaria, Nigeria . Bulletin of Animal Production in Africa 43: 163-165.

AOAC, 1980. Association of Official Analytical Chemists. Official Methods of Analysis, 13th ed. Association of Official Analytical Chemists. Benjamin Franklin Station. Washington, DC.

Bath, R.L. Dickson, D., Tucker, H.A. and Robert, D.P. 1978. Dairy cattle principles, practices, problems and profits. $2^{\text {nd }}$ ed. Lon and Feibiger Philadelphia (Abstract).

Bemji, M. N. 2003. Milk production and preweaning growth of West African Dwarf and Red Sokoto goats. Ph.D Thesis. Dept. of Animal Breeding and Genetics, Univ. of Agric. Abeokuta. Nigeria.

Chamber1ain A 1989. Milk Production in the Tropics. Intermediate Tropical Agriculture Series (W J A Payne, Editor). Longman Group UK Limited, pp 210-219.

Dangut, A.J 1991. Effect of stage lactation on the milk composition of Bunaji cattle. B.Sci Thesis, University of Agriculture, Markudi Nigeria.

Devendra, C. and Burns, M. 1983. Goat production in the tropics. Commonwealth Agricultural Bureau (CAR) UK: 64-73.

Ehoche, O.W. and Buvanendran, V. 1983. The yield and composition of milk and pre weaning growth rate of Red Sokoto goats in Nigeria. World 
Rev. Anim. Prod. Vol. XIX (2): 19-24.

Fuertes J.A., Gonzalo C., Carriedo J.A., Primitivo F.S. 1998. Parameters of test day milk yield and milk components for dairy ewes. J. Dairy. Sci., 81, 1300-1307.

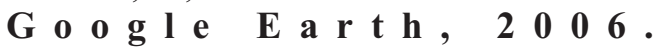
http://www.google/earth.hmtl.

Gerber, N., 1960. Practical treaty for the analysis of milk and for the control of dairy products, 11th ed. Editorial Dossat S.A., Madrid, Spain, pp. 20-42.

James, I. J. 2000. Changes in the udder traits of West African Dwarf, Red Sokoto and Sahel goats during pregnancy and lactation and their effects on partial daily milk yield. M. Agric. Dessertation, 101pp.

Jennes, R. 1980. Composition and characterization of sheep milk.Reviewed 1968 - 1979, J. Dairy Sc. 63: 1605-1630.

Khatkar, M.S. and Sethi, R.K. 1995. Influence of body size on milk production performance in Murrach buffaloes. Indian J. Dairy Sci. 48(5): 374-377.

Knight, C. H. and Wilde, C. J. 1993. Mammary cell changes during preganacy and lactation Livest, Prod. Sci. 35:3-19

Kuchtík, J., Šustová, K., Urban, T. And Zapletal, D. 2008. Effect of the stage of lactation on milk composition, its properties and the quality of rennet curdling in East Friesian ewes. Czech J. Anim. Sci., 53, (2): 55-63.

Nuru S. 1985. Trends in small ruminants production in Nigeria. In: proceedings of national conference on small ruminants production, NAPRI, Shika, Nigerian 6-10 March, pp.36-48.

Oddy V. H., J. M. Gooden and Annison, E. F. 1984. Partitioning of nutrients in
Merino ewes. I. Contribution of skeletal muscle, the preganant uterus and the lactating mammary gland to total energy expenditure. Australian Journal of Biological Science, 37: 375-388

ORBDA, 2004. Ogun-Osun River Basin Development Authority. Reports on meteorological data for the experimental station geographical zone, Abeokuta, Nigeria.

Pavič V., Antunac N., Mioč B., Ivankovič A., Havranek J.I. 2002. Influence of stage of lactation on the chemical composition and physical properties of sheep milk. Czech J. Anim. Sci., 47, 80-84.

P lou mi K., B elibas a ki S ., Triantaphyllidis G. 1998. Some factors affecting daily milk yield and composition in a flock of Chios ewes. Small Rumin. Res., 28, 89-92.

National Programme on Food Security, 2008. Cited in Promoting policy and legislative intervention for food security in Nigeria; an audit of existing policies on food reserve system, 2012. Civil Society Legislative Advocacy Centre (CISLAC) Abuja, Nigeria 307pp.

Said, S.I and Al-Jaryan, L.J.F. 1992. Milk yield of Angora goats in Iraq. In: Genetic Conservation of Domestic Livestock Vol. 2. Alderson, L. and Bodo, I(Eds) CABI: 186-191.

Sahan N., Say D., Kacar A. 2005. Changes in chemical and mineral contents of Awassi ewe's milk during lactation. Turk. J. Vet. Anim. Sci., 29, 589-593.

Singh, R.P., Guptar, R. and Tomar, S.S. 1993. Udder shapes and their relationship with milk production in crossbred cows. Indian J. Dairy Sci., 46(7): 289-291 
Systat, 1993. Systat Computer Package. Version 502. Systat Inc., 1800, Sherman Ave., Evanston, IL., USA.

Voutsinas L.P., Delegiannis C., Katsiari M.C., Pappas C. 1988. Chemical composition of Boutsiko ewe milk during lactation. J. Dairy Res., 43, 766-771.
Williams T .J, 2008. Effects of milking frequency on milk yield and udder regression in west African Dwarf goat (Ph.D thesis). Department of Animal physiology, University of Agriculture, Abeokuta. Nigeria, 127pp.

Received: 7th August, 2011 Accepted: 2nd April, 2012 